\title{
Shale oil and ecology in Australia - the search for balance
}

Today Australia is one of the main mineral resources exporters in Asia. Besides, the country possesses huge reserves of shale oil and gas. The estimation of these resources extraction potential without any harm to country's ecology and society is one of the key aims of this article. The authors research an export and import dynamic of hydrocarbon by Australia with the aim to identify an economic effect from the beginning of shale oil extraction in 2011. Besides, according to expert community's opinion, there is the emission dynamic of carbon dioxide, which is one of the key factors, determining the environment pollution after the beginning of shale oil extraction in Australia. The major challenge of the article is to estimate the difficulty in real correlation between the ecology and the financial benefits for the economy, as these two factors are loosely connected and the index of additional harm to wildlife and people cannot be directly calculated in financial losses. The major contribution of the article is the development and comparison of the two scenarios of oil extraction and exports with or without frocking bans in Australia. The authors come to the conclusion that positive effects from shale oil and gas extraction for country's economy do not surpass negative effects for ecology; thus, the authors suggest to use the shale oil reserves only as the strategic resource for economic recovery after crises and at the present moment it should be to realize the shale oil extraction in test mode.

Keywords: Shale oil and gas, Australia, ecology, economy, carbon dioxide, export, import.

\subsection{Introduction}

$\mathrm{N}$ owadays it is difficult to overestimate the shale oil and gas role in the world economy. By the example of the USA it is possible to say certainly that shale

Messrs. Elnur T. Mekhdiev, Cand. Sci. (History.), Associate Professor. Center for Analysis, Risk Management and Internal Control in Digital Space, Financial University under the Government of the Russian Federation, 49, Leningradsky Prospekt, Moscow, 125993, Igbal A. Guliev, Cand. Sci. (Econ.) and Yulia V. Solovova, Cand. Sci. (Law), Associate Professor. International Institute of Energy Policy and Diplomacy, MGIMO University. 76, Prospect Vernadskogo Moscow, 119454, Russia. E-mail: e.mehdiev@gmail.com / gulievia@mail.ru / yulia.solovova@gmail.com oil can become a driver of energy revolution for the particular economy [1], [2], [3]. A number of European and Asian countries try to repeat the success of the American shale revolution; moreover, the biggest shale oil reserves according to EIA estimations [4] are located in the countries with energy balance deficit. The development of shale oil extraction from tight gas reservoirs technology urges considerable financial receipts and active cooperation with the countries, which have the high accompanying industries development level, in particular, this is about engineering and chemical industry.

The Australia's place in this process is not determined exactly, because the forbiddance on frocking was taken off only in 2011. Nevertheless, the country has both financial resources, and the admission to the technologies of the oil and gas extraction from tight gas reservoirs. As the country's economy depends largely on mining, the development of the new extraction industry will have the positive effects to the country's economic growth tempos and it will also help to solve some social problems. Nevertheless, today the oil and gas extraction from tight gas reservoirs technology is one of the less ecologically friendly in the oil and gas production [5].

According to abovementioned, there is a very important question - how much is Australia ready to reconcile with the ecological situation degradation in the country, as it has been already fighting with the consequences of the rash technological development? (for example, there is no any ozone layer above the country [6], [7].

In this context the problem of searching balance between economic goods and ecological situation and the heritage for future generations become the most actual and it must stands in the focus of the scientific and professional interest. The authors are searching for answer - how much is it admissible to expand the shale oil fields in Australia? And another question is what consequences it will lead to.

\subsection{Methodology}

The Australia's territory of geological research, made by EIA in 2013 [8] is the basis of this article. This data gives an opportunity to judge about the number of shale resources, located in Australia. As there is no information is available 


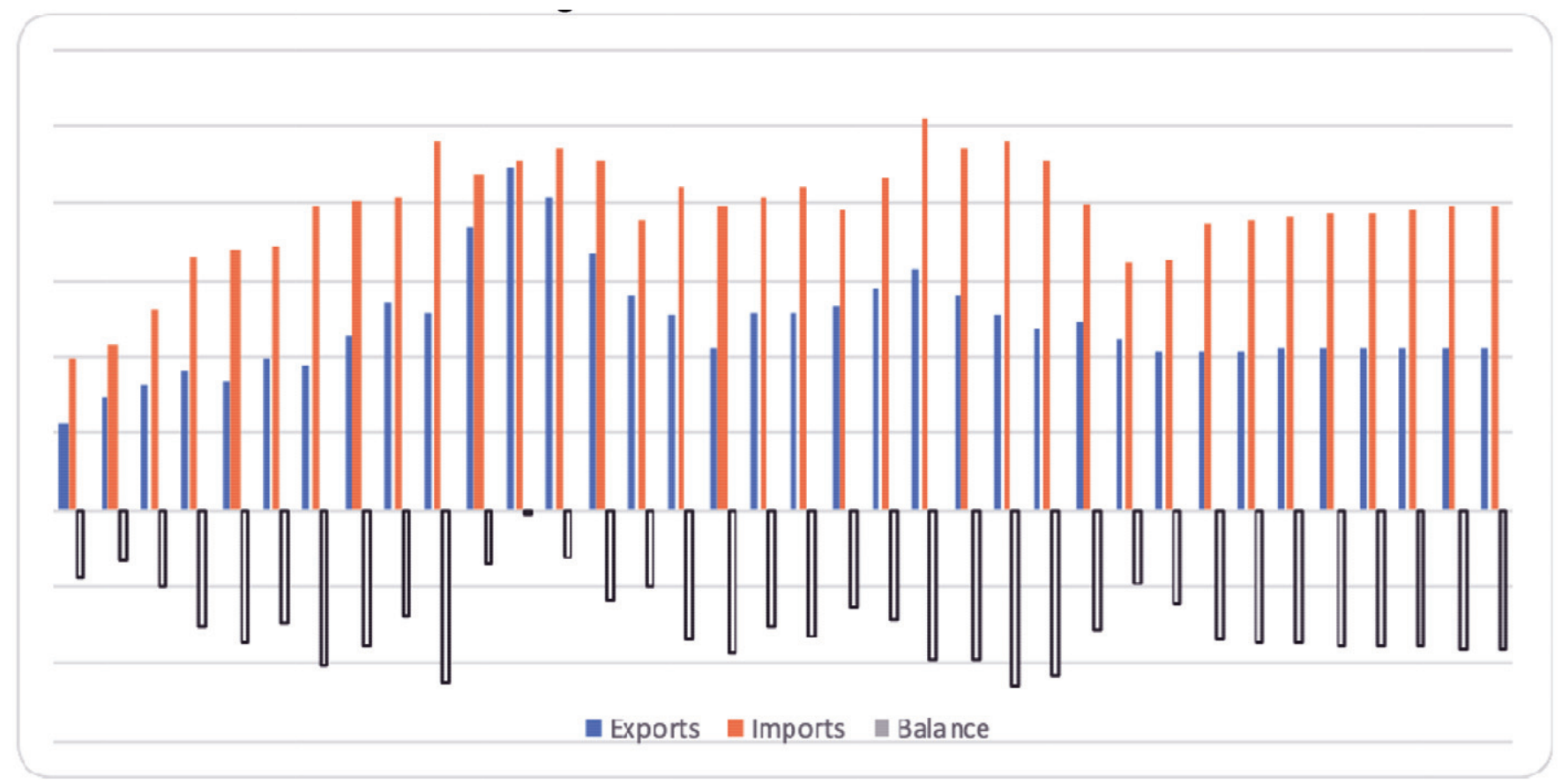

Fig.1 Oil and gas export and import in Australia (calculated by the authors) [11].

on shale oil and gas reserves and extraction for retrospective analysis, it is necessary to use hydrocarbons import and export data; and this information will allow building an energy balance, which will become the basis for analytic research, concerning oil and gas role on the Australian economy.

An economic benefit for the country is evaluated by the authors according the following formula:

$$
\left\{\begin{array}{c}
E P=(E x-I m) / \triangle C O_{2} \\
C O_{2} \sim d, t \\
E x-I m=B \sim t
\end{array}\right.
$$

where Ex, Im and B - export, import and the Australia's energy balance; $\mathrm{t}$ - time factor; Cons - inner electrical energy consumption; $\mathrm{CO}_{2}-$ a carbon dioxide emission; $\mathrm{d}$ - dummy variable.

One of the main ecological arguments against the shale oil extraction increase in Australia consists of in that oil supply increase will lead to the oil prices drop and the carbon dioxide emission to atmosphere will grow; hence, the ecological effect will be estimated as the forecast of the carbon dioxide emission growth in Australia with the dummy variable use, which presents the oil extraction:

$$
\left\{\begin{array}{c}
C \mathrm{O}_{2} \sim t, d \\
d=0, \text { if } n<2011, \text { else } 1
\end{array}\right.
$$

Then, the authors estimate the economy's effectiveness tempos growth and compare them with carbon dioxide emissions tempos growth; thus the authors estimate the final effectiveness of the shale resources extraction in the country.

\subsection{Estimation of the economic effect}

Within the research, shale oil export and import cannot be used nowadays as its extraction is being realized in the concessions and in this situation there are no statistically big numbers for the country. Moreover, all technological process is being realized in the whole by eight companies at only one of the thirteen Australia's fields [9], [10]. It is necessary to mention that approach to the industry development in Australia contrary to the USA is accurate; there is no dramatic boom of shale oil extraction, which led, for example, to the ecological situation degradation in the US southern states. Today there is only a test extraction mode, though the first attempts of shale oil extractions were made in the end of 1990s.

Let us consider oil export and import by Australia. It is one of the important articles of the both energy balance and country's budget. The main export and import indicators and calculated balance are shown in Fig.1.

As it follows from Fig.1, the country's energy balance has been remaining negative for the whole period; there were two export growth peaks in 2001 and in 2011. They can be connected with the crisis phenomenon in the world economy such as dotcom crisis in the end of 1990s and the world financial crisis. Data analysis shows us how oil and gas export incomes are used in Australia: they cover deficit budget items and they also form a basis for economy's growth tempos recovery. In fact, Australia's oil and gas export is an instrument of country's export base expanding and it does not lie in export framework in contrast to mineral resources. It must be noticed that oil and gas import drop in 2012 is 
connected with the shale oil extraction growth in the country; the Australia's policy consists of in the primary providing with resources in its inner demand, and there is also a general lowering of the oil and gas consumption in connection with green technologies growth too [12], [13].

The forecasted slow import growth and stable export show that without dynamics in the shale oil extraction sphere [14], Australia will have to increase hydrocarbon import to satisfy its growing economy. Thus, today there is a balance between green and traditional energy sources in Australia and further increase of green energy sources use will lead to additional economic spending.

The other important part of the economic impact estimation, that shale oil has on the Australian economy is the assessment of the competition for markets. Australia is one of the major exporters of the LNG in the world, lately it is rivaled by the USA [15] - a structural and stochastic optimal model for projections of LNG imports and exports in AsiaPacific). A very important part of this competition is the Chinese market. It is one of the biggest and most dynamically developing energy markets in the world, so both countries are interested in gaining higher shares of it. The recent trade deal between the USA and China on the growth of the American exports to the country inevitably harms the Australian industry. As it follows from the, Australia is aimed at exporting hydrocarbons, as it has the significant potential in the South-East Asia region. At the same time, it is noteworthy, that the latest economic factors have negative influence on the Australian exports. The major of them are:

1. Lowest oil prices in the recent years

2. COVID-2019 pandemic and the cut down of demand for hydrocarbons in the context of general economic slowdown.

3. US-China deal, mentioned earlier.

4. Unclear future of the global economy in general.

5. Unclear course of politics of the US after the president elections, just as the unclear situation about elections [16].

6. High quantity of isolation measures between the countries connected with both COVID-2019 and significant problems arising in the regional politics [17].

In addition to that, US-China deal affects more than simple trade, it pushes backwards the cooperation on technology exchange between the USA and its allies. The future of the energy industry of Australia is unclear, so is the future of shale oil and gas industry in the country. Still, under such pressure from negative external factors, it is highly likely that Australian energy companies will not be able to cope with high competitions and shale oil and gas exports from the country will fall significantly.

\subsection{Estimation of the ecological and general effect}

Let us consider an ecological aspect of the shale oil extraction.
First, let us determine main theoretical threats of frocking, which are often spoken that they are critical [18].

1. A seismic activity increase in the region;

2. An underground water pollution;

3. A biodiversity lowering;

4. The development of the oncologic and other diseases in humans, living near the extraction's territories.

Nowadays, in Australia, the extraction can be realized at the Beetaloo field, situated in the north of the country in the relatively desert area; there is only one city of a regional subordinance, situated near extraction place and it is called Birdum. In the context of above mentioned criteria, the last item from the main threats is not actual. Nevertheless, oil field occupies the water region Lake Woods and the basin of the river Diamantine; that is why there is a threat to the biodiversity and the fresh water quality in these ponds. There is also a seismic activity problem. Wherein, a carbon dioxide emission growth to the atmosphere is another terrible problem taking place in Australia [19]. That is why let us consider the forecast of the carbon dioxide emission growth with and without the shale oil extraction in the north of the country (Fig.2).

To make clear conception of the Fig.2, let us see Table 1. It demonstrates the difference between two scenarios.

Thus, it can be concluded that shale oil extraction influence on carbon dioxide emissions is insignificant. It can be noticed that this effect, nevertheless, has a cumulative nature and this can change the situation greatly in the distant future.

Let us calculate the general effect from shale oil extraction permission or forbiddance in Australia and the authors will answer the question, how much this effect is economically justified. Let us go through the Table 2.

TABle 1: The PeRCENTAGE OF DIFFERENCE BETWEEN SITUATION DEVELOPMENT SCENARIOS (UNITS OF MEASUREMENT FOR FROCKING SAME AS FIG.2)

\begin{tabular}{lccc}
\hline Year & $\begin{array}{c}\text { Frocking } \\
\text { allowed }\end{array}$ & $\begin{array}{c}\text { Frocking } \\
\text { banned }\end{array}$ & $\begin{array}{c}\text { The difference } \\
\text { in } \%\end{array}$ \\
\hline 2015 & 15,236473 & 15,254422 & $0,1 \%$ \\
2016 & 15,073979 & 15,107814 & $0,2 \%$ \\
2017 & 14,838487 & 14,885628 & $0,3 \%$ \\
2018 & 14,544458 & 14,603762 & $0,4 \%$ \\
2019 & 14,201874 & 14,273037 & $0,5 \%$ \\
2020 & 13,817621 & 13,900819 & $0,6 \%$ \\
2021 & 13,396452 & 13,492121 & $0,7 \%$ \\
2022 & 12,941646 & 13,050355 & $0,8 \%$ \\
2023 & 12,455466 & 12,577845 & $1,0 \%$ \\
2024 & 11,939473 & 12,076171 & $1,1 \%$ \\
2025 & 11,394745 & 11,546409 & $1,3 \%$ \\
\hline
\end{tabular}

Calculated by the authors 


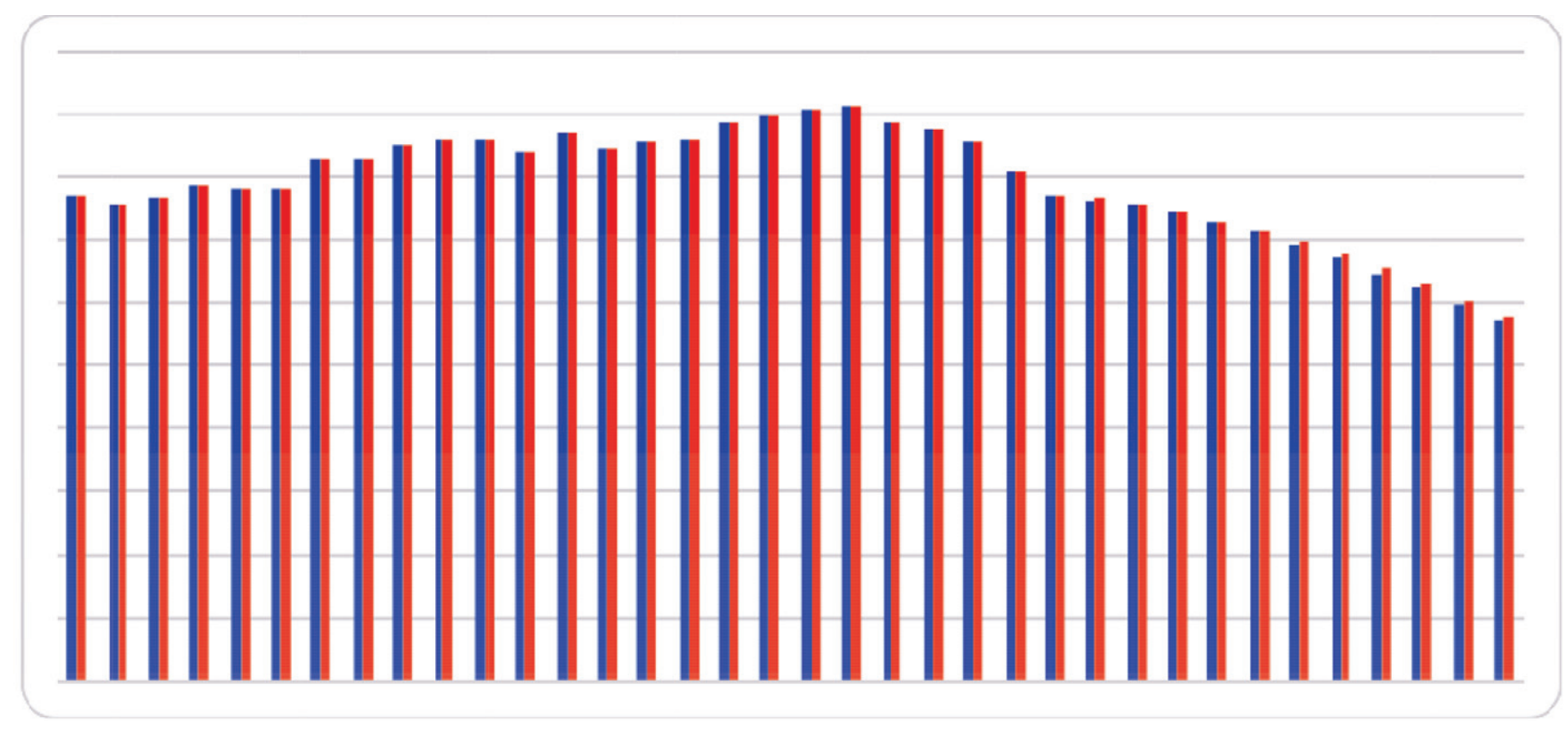

Fig.2 The carbon dioxide emission in tons per capita (worked out by the authors) [20]

TABLE 2: ThE COMPARISON OF DEFICIT GROWTH TEMPOS OF THE ENERGY BALANCE AND CARBON DIOXIDE EMISSIONS

\begin{tabular}{lcccccc}
\hline & 2019 & 2020 & 2021 & 2022 & 2023 & 2024 \\
\hline Energy deficit growth & $1,08 \%$ & $1,07 \%$ & $1,06 \%$ & $1,07 \%$ & $1,05 \%$ & $1,04 \%$ \\
CO2 emissions growth & $0,5 \%$ & $0,6 \%$ & $0,7 \%$ & $0,8 \%$ & $1 \%$ & $0,03 \%$ \\
Efficiency & & 0,1 & 0,1 & 0,1 & 0,1 & 0,1 \\
\hline
\end{tabular}

Calculated by the authors

As the Table 2 shows, the energy balance deficit growth during the time is lowering, but for the researched period it is $-0.05 \%$, but at the same time the indicator of carbon dioxide emissions growth is $+0.8 \%$. Thus, shale oil extraction effectiveness in Australia in the viewpoint of the ecological aspect is negative.

\subsection{Discussion}

Within the research, only one consequence of the shale oil extraction developing for ecology is shown. As it is obvious from the analysis, the shale oil developing economic effectiveness in Australia is lower than a potential harm done to ecology; this fact shows us the negative nature of the shale oil revolution in Australia. Wherein, as it was said within the discussion about the main risk sources of the shale revolution, frocking assists the underground waters pollution. Moreover, in Australia, the situation with fresh water is too complicated [21], and it must be noticed that river Diamantine flows into the ocean not far from Melbourne and Adelaide, that is why the harm for the population may be rather considerable than it is supposed.

There is also another important aspect: the shale oil extraction does not give a considerable contribution to the economy and this extraction, to a high degree, affects to a private prosperity; that is why the matter about the shale oil extraction social effects must be considered in the viewpoint of the income redistribution in favour of the country and society. Wherein, it should be remembered, the shale oil extraction is a high risk venture [22], [23], this means that in the considered context, risks are transferred to the society. Thus, the main principles of pubic private partnership are broken, for example, the positive external effect from it.

According to the research results, it can be concluded, the most favourable scenario of the shale oil revolution development in Australia will be slow and well-designed development of the oil extraction from tight gas reservoirs separate regions in the direction of the ecologically responsible approach to its development. The analysis of the company's actions consequences for ecology must be the basis for this approach according to the worst scenario. If we follow this recommendation and use oil export as the economic support instrument during difficult periods and also as its growth acceleration source during recessions period, the shale revolution in Australia will be completely socially positive and economically advantageous phenomenon; otherwise the country will face with negative consequences shale oil developing as in Texas, but with considerably bigger negative effects. 


\subsection{Conclusion}

As it was shown in the analysis, the combination of the ecology and economic advantage from the shale revolution in Australia is possible only under slow shale revolution development. Nowadays, technologies do not allow completely to realize frocking process without serious harm to environment.

Nevertheless, little deviation values in the ecological situation and advantages, which can be given by the shale oil extraction during the crisis periods, lead to the fact that the rational decision for the country consists of the readiness to the shale revolution as it is inevitable; but the next crisis is also inevitable. That is why it is necessary to start the shale oil fields developing in the test mode (as it is being realized at Beetaloo). This will allow in the long-term period to lower risks, connected with fast tempos of the shale oil extraction development and it will also lower the necessary investments (hence, financial shocks) for country's financial system elements such as banks and country's population. And it will allow controlling more correctly ecological situation changes.

Still, it is noteworthy that in the modern conditions the future of the shale industry in the country looks murky as the pandemic and high external pressure along with the expectations of the future crisis will contribute to the low inflow of investments in the industry.

\section{References}

1. Konoplyanik, A. (2016): The US Shale Gas Revolution and its Economic Impacts in the Non-US Setting: A Russian Perspective. Handbook of Shale Gas Law and Policy: Economics, Access, Law, and Regulations in Key Jurisdictions. Edited by H. Tina. Cambridge: Intersentia, Vol. 18. P. 65-106.

2. Anderson, J. (2019): US Shale Industry Credited with Driving 10\% of us GDP Growth. Energy in Depth. 26.08.2019. Available at: URL: https:// www.energyindepth.org/us-shale-industrycreditedwith-driving-10-of-us-gdp-growth/

3. Janda, K., Kondratenko, I. (2018): An Overview of Economic Impacts of U.S. Shale Gas Revolution. MPRA. 16.01.2018. Available at: URL: https:// mpra.ub.uni-muenchen.de/83946/

4. World Shale Resource Assessments. (2015): U.S. Energy Information Administration (EIA). 24.09.2015. Available at: URL: https://www.eia.gov/analysis/ studies/worldshalegas

5. Zhang, D., Yang, T. (2015): Environmental Impacts of Hydraulic Fracturing in Shale Gas Development in the United States. Petroleum Exploration and Development. Vol. 42. No. 6. P. 876-883.

6. The Ozone Layer. Australian Government: Department of Agriculture, Water and the Environment. Available at: URL: https://www.environment.gov.au/protection/ ozone/ozonescience/ozone-layer

7. Dargaville, R., Schofield, R. (2015): The Hole in the Ozone. The University of Melbourne. 21.12.2015. Available at: URL: https://pursuit.unimelb.edu.au/ articles/the-hole-in-the-ozone

8. Technically Recoverable Shale Oil and Shale Gas Resources: Australia. (2013): U.S. Energy Information Administration (EIA). Available at: URL: https:// www.eia.gov/analysis/studies/worldshalegas/pdf/ Australia_2013.pdf

9. Britt, A., Senior, A., Summerfield, D., Hughes, A., Hitchman, A., Champion, D., Huston D., Simpson, R., Kay P., Sexton, M., Schofield, A. (2019): Australia's Identified Mineral Resources 2018. Canberra: Geoscience Australia, 77 p.

10. Shale Oil Development in Australia. Lock the Gate Alliance. Available at: URL: https://www.lockthegate. org.au/shale_oil_development_in_australia

11. Data and Statistics: Crude Oil Imports vs. Exports, Australia 1990-2018. International Energy Agency (IEA). Available at: URL: https://www.iea.org/data-andstatistics? country= AUSTRALI\&fuel= Oil \& indicator $=$ Crude $\% 20$ oil $\% 20$ imports $\% 20 v s . \% 20$ exports

12. Blakers, A., Stocks, M., Lu B. Australia: The Renewable Energy Superstar. Australian National University. Available at: URL: http://re100.eng.anu.edu. au/publications/assets/100renewables.pdf

13. Li, H.X., Edwards, D.J., Hosseini, M.R., Costin, G.P. (2020): A Review on Renewable Energy Transition in Australia: An Updated Depiction. Journal of Cleaner Production. Vol. 242. P. 118475.

14. Thornhill, J. (2019): The Next «Ferrari of Shale» May be Hiding in Australia's Outback. Bloomberg. 02.05.2019. Available at: URL: https:// www.bloomberg.com/news/articles/2019-05-01/incrocodile-dundee-country-australia-huntsfor-giantgas-prize

15. Tom, Kompas, Tuong, Nhu, Che. (2016): A structural and stochastic optimal model for projections of LNG imports and exports in Asia-Pacific. Heliyon. Volume 2, Issue 6, pp. 1-35.

16. David, Siders. (2020): Trump sees a 'rigged election' ahead. Democrats see a constitutional crisis in the making. Available at: https://www.politico.com/news/ 2020/05/25/donald-trump-rigged-election-talk-fears274477

17. Esposito, E. (2020): Systemic Integration and the Need for De-Integration in Pandemic Times. Sociologica, 14(1), 3-20. 